\title{
Little Criminals: the study of a New Zealand Boys' Home
}

\author{
David Cohen \\ Random House, Auckland, 2011 \\ ISBN 9781869796938, pp. 288, eBook, NZ\$14.99
}

$\mathrm{T}$

This is a book about the lived experience of being in short-stay residential care in Aotearoa New Zealand. It is also a chronicle of the end to the undiscriminating use of youth institutions and the anguish that followed. In the autumn of 1975, author David Cohen, spent a short period in the Social Welfare Boys Home, Lower Hutt, (commonly known as 'Epuni', after the suburb). As Cohen explains, he set out to write an account of the 1980s demise of residential care as a routine social work intervention in the lives of children and young persons, but later decided to narrow the focus on to Epuni alone. 'Focus' is a key word here, because the metaphors used, the shifts from the personal to the social, and the mixture of researched fact and anecdotal authority all go to make this a difficult book to review. Very wisely, Cohen, now a journalist, makes the disclaimer that "It is not an authorised account or meant to serve as a work of historical scholarship." The text was not vetted by any outside organisation or individuals" (p. 267). It covers a wide ground and joins a much-needed genre of consumer accounts of being in care.

Chapter one begins with the recurring metaphor of life as a struggle akin to boxing, icons of which sport drove Cohen's imagination and interest. We find him picked up, processed and locked up at Epuni. Next, he uses the reflections of career criminal Arthur William Taylor to suggest that Epuni was the germinator of that career. Chapters three, four and five paint pictures of the people, routines and rituals which prevailed there in the 1970s. The next chapter introduces the long-serving inaugural principal, Maurice Howe, whose quoted reflections also end the book. From here on, it gets even denser and anecdotal. A whole section is devoted to a convicted paedophile who earlier was a teacher at Epuni. Expert informants are quoted, such as Mike Doolan (residential manager and later Chief Social Worker), Aussie Malcom (one-time Child Welfare employee, later Minister of Social Welfare, and foster-father of an Epuni resident) and Gary Hermansson (one-time housemaster and now Emeritus Professor of Education). There are photographs of the home and the people mentioned, most named, but some of people well-known in the social services industry inexplicably unnamed (for example, Hermansson). It goes on to ponder on the Department's many institutions and the forces which drove them to be abandoned in the late 1980s. Tellingly, especially for social workers, it describes in detail the legal redress of historical abuse grievances, and the operation of the legal firm of Sonya Cooper. The final chapter picks up the boxing metaphor again, as Cohen attempts to marshal his thoughts and feelings about his experiences in care.

Social work, its personnel, practices and its folklore, can benefit immensely from consumer accounts. Cohen devotes a couple of pages to his illustrious predecessor John A. Lee, but none of the others. Leigh Bonheur (pseudonym) got Child Welfare in a tizz when in 1971 she wrote an expose of the Christchurch Receiving Home (Hand me down child); twenty-two years later Robbie Sinclair (All God's Children) put down all his grievances about the Christchurch 
Boys' Home and Hokio School. The blurb to this book neatly sums up the residential care dilemma that "acts of physical and sexual abuse against a child cause them to be sucked into a corrosive and corrupting spiral of self-doubt, social abandonment, and eventually and inevitably an aggressive disregard for social structure and standards". I would have expected references to Cohen's near-contemporary (by one decade) author Alan Duff, who followed Lee's example by writing gritty factual and fictionalised accounts of his time at the Hamilton Boys Home.

There is enough material documented in the references and commentary to underpin several doctoral theses. Regrettably, the whole still remains something of jumble, probably the result of trying to make a popular (that is, saleable) account out of a specialised (boring) topic. The boxing allusions and journalistic scepticism will turn off social workers, and general readers will be lost in the discussions about political and departmental machinations. Worse, by failing to get his expert informants to check his text, Cohen gets simple matters of fact woefully wrong. My notes on corrections ran to two pages, but as just one example, Maurice Howe was initially a "Physical Welfare Officer", not therapist, he never worked in Auckland, and he has more than two children. Cohen also failed to understand that the principal of any short-stay institution was not actually the "designated controlling officer"; that responsibility rested with the district director. Perhaps it was my failure of imagination, but despite many hints, asides (such as a mention that as a teenager he worked in the Department of Social Welfare district office) and casual inferences, I never formed any concrete visualisation of Cohen the adult, past the bewildered adolescent of Chapter one. It does, of course, take considerable fortitude to disclose oneself to the printed page, and we ought to salute Cohen for that. Despite these gripes, I found the book fascinating and I believe that it has made a real contribution to our consumer accounts. Hopefully, it will retain enough of its potency to remain useful to consumers, students, and serious scholars in the future. 